\title{
Weight gain, behavioral and cortisol changes after orchiectomy with or without local anaesthesia in piglets
}

\section{Ganho de peso, comportamento e alterações no cortisol após a orquiectomia de leitões com ou sem anestesia local prévia}

\author{
Leticia Sturlini Barticciotto ${ }^{1}$; Stelio Pacca Loureiro Luna ${ }^{2 *}$; \\ Ślvia Elaine Rodolfo de Sá Lorena ${ }^{3}$; Filipe Garcia Telles ${ }^{4}$; Dirlei Antônio Berto ${ }^{5}$
}

\begin{abstract}
The aim of this study was to investigate the effect of intratesticular local anesthesia on weight gain and behavioral and cortisol changes in piglets submitted to castration. Study design was a randomized controlled trial. Twenty-nine male Landrace crossbred piglets aged 3 to 6 days were used. The piglets were randomly divided into two groups: orchiectomy with anesthesia (A, $n=15)$ and orchiectomy without anesthesia (NOA, $n=14$ ). Piglets in the A and NOA groups were treated with $0.5 \mathrm{~mL}$ of intratesticular $2 \%$ lidocaine with a vasoconstrictor in each testicle and $0.5 \mathrm{~mL}$ of intratesticular $0.9 \%$ sodium chloride, respectively. Blood samples were collected from all animals immediately after surgery and at 3 and 6 days postoperatively for measurement of the serum cortisol concentration. Behavior was assessed daily for 6 days by two observers blinded to the treatment. Weight was measured at the same time as cortisol measurement. Analysis of variance followed by the Student-Newman-Keuls test was used to investigate differences in time within and between the two groups. Mean times of six evaluations done for 90 minutes during 6 days of each behavior were compared by Tukey $t$ test. The level of statistical significance was $5 \%$. The serum cortisol concentration was higher immediately after surgery than at 3 and 6 days postoperatively in both groups. Weight gain was greater at 3 and 6 days postoperatively in the A group than in the NOA group. Intratesticular local anesthesia before castration in piglets is technically practical, is in accordance with good welfare practice, and improves short-term weight gain in piglets submitted to castration.
\end{abstract}

Key words: Behavior. Castration. Lidocaine. Pig.

\section{Resumo}

O objetivo deste estudo foi investigar o efeito da anestesia local intratesticular prévia à castração sobre o ganho de peso, comportamento e alterações no cortisol de leitões. O delineamento experimental adotado foi inteiramente casualisado. Foram utilizados vinte e nove leitões mestiços Landrace - Large White do sexo masculino com idade de 3 a 6 dias. Os leitões foram divididos aleatoriamente em dois grupos:

\footnotetext{
1 Servidor da Secretaria de Agricultura e Abastecimento do Estado de São Paulo, Águas de Lindóia, SP, Brasil. E-mail: levet2006@ yahoo.com.br

2 Prof., Departamento de Cirurgia e Anestesiologia Veterinária da Faculdade de Medicina Veterinária e Zootecnia, FMVZ, UNESP, Botucatu, SP, Brasil. E-mail: stelio@fmvz.unesp.br

3 Prof $f^{a}$, Unidade Acadêmica de Garanhuns, Universidade Federal Rural de Pernambuco, UFRPE, Garanhuns, PE, Brasil. E-mail: silvia@mpc.com.br

4 Pós-graduando pelo Programa de Pós-graduação em Zootecnia, FMVZ/UNESP, Botucatu, SP, Brasil. E-mail: garciatelles_34@ hotmail.com

5 Prof., Departamento de Produção Animal da Faculdade de Medicina Veterinária e Zootecnia, FMVZ, UNESP, Botucatu, SP, Brasil. E-mail: dirleiberto@fmvz.unesp.br

* Corresponding author
} 
orquiectomia com anestesia ( $\mathrm{A}, \mathrm{n}=15)$ e orquiectomia sem anestesia (NOA, $\mathrm{n}=14)$. Aos leitões do grupo A foi administrado $0,5 \mathrm{~mL}$ de lidocaína $2 \%$ intratesticular com vasoconstritor em cada testículo, e no grupo NOA administrou-se $0,5 \mathrm{~mL}$ de $\mathrm{NaCl} 0,9 \%$ intra testicular também em cada testículo. Amostras de sangue foram coletadas de todos os animais imediatamente após a cirurgia e posteriormente aos $3 \mathrm{e}$ 6 dias após a cirurgia para a medição da concentração de cortisol sérico. O comportamento foi avaliado diariamente durante 6 dias por dois observadores que desconheciam o tratamento. O peso foi medido ao mesmo tempo que o cortisol sanguíneo. Foi realizada a análise de variância, e o teste Student-NewmanKeuls para contraste entre médias. O tempo médio de seis avaliações realizadas por 90 minutos durante 6 dias para cada comportamento foi comparado pelo teste de Tukey. O nível de significância estatística foi de 5\%. A concentração de cortisol sérico foi maior imediatamente após a cirurgia do que após 3 e 6 dias de pós-operatório em ambos os grupos. $\mathrm{O}$ ganho de peso foi superior aos 3 e 6 dias após a cirurgia no grupo A em relação ao grupo NOA. A anestesia local intratesticular antes da orquiectomia em leitões é prática, auxilia na manutenção das boas práticas de bem-estar animal, e melhora o ganho de peso a curto prazo em leitões submetidos à castração.

Palavras-chave: Castração. Comportamento animal. Lidocaína. Suíno.

\section{Introduction}

Pork is the most extensively consumed meat worldwide (USDA, 2015). This is probably related to tradition, competitive prices when compared with other products, low amounts of fat, palatable flavor, favorable texture quality, and consistent marketing programs (ROPPA, 2003; FAOSTAT, 2013).

New animal welfare regulations require innovative raising perspectives to adapt to the demanding world market (DRANSFIELD, 2005; NGAPO et al., 2007a, 2007b). Animal welfare, environmental issues, and food security are considered to be the three major challenges that will confront the agriculture business in the coming years (ROLLIN, 1995). The consumer desires to eat meat of "ethical quality", which is meat that originates from animals raised, treated, and slaughtered using systems that promote the well-being of animals and that are sustainable and environmentally acceptable (WARRIS, 2000). There is strong evidence that highquality meat originates from good animal welfare. Poor welfare produces serious consequences at all stages of production and compromises the final product (BEATTIE et al., 2000).

Surgical castration is a practice that induces great suffering in animals and can lead to problems such as bleeding, infection, and loss of production efficiency because of acute or chronic stress (SCHULZ et al., 2007; ZÖLS et al., 2006). Legislation regarding the need for castration before slaughtering of pigs is variable worldwide. Surgical castration is no longer accepted in countries of the European Union (THUN et al., 2006). Several countries have already banned or are in the process of banning the need for castration before slaughtering (JÄGGIN, 2001). The main benefits of castration include removal of the unpleasant odor and flavor observed when one eats meat from noncastrated male pigs and reduction of aggressive behavior (THUN et al., 2006).

In one study, castration without anesthesia in pigs up to 7 days of age produced a greater increase in catecholamine concentrations than in piglets submitted to castration with anesthesia (SCHULZ et al., 2007). Otherwise, the effect of castration on cortisol concentrations has been inconclusive and the endocrine and behavioral changes produced by castration may be maintained for 4 days (HAY, 2003).

Although the administration of analgesia and anesthesia before castration consumes both time and money, the demand for these techniques during castration in piglets has increased because they reduce the pain and suffering associated with this procedure (HANSSON et al., 2011; KLUIVERSPOODT et al., 2012). However the effect of local anesthesia in short-term weight gain has not been demonstrated yet (HANSSON et al., 2011; KLUIVERS-POODT et al., 2012, 2013). 
The most common anesthetic techniques for castration in piglets are isoflurane or local anesthesia. Studies have shown that isoflurane anesthesia does not efficiently reduce pain after castration when compared with castration without anesthesia (SCHULZ et al., 2007), however, intratesticular, scrotal sac, and spermatic cord anesthesia are reportedly equally effective in reducing the endocrine and behavioral responses after castration (HAGA; RANHEIM, 2005).

The aim of this study was to investigate the effect of intratesticular local anesthesia on weight gain and behavioral and cortisol changes in piglets submitted to castration.

\section{Materials and Methods}

This study was conducted at a commercial pig farm after obtaining approval from the University Animal Research Committee - process number 76/2013-CEUA. Twenty-nine 3- to 6-day-old male Landrace crossbred piglets from six different litters were used. The sows and litters were maintained in 1.80-2.20 $\mathrm{m}^{2}$ cages from birth; all cages were equipped with creep feed, feeders, and drinkers specific to sows and piglets. They were fed twice daily. The piglets were free to move and the litters were randomly divided into two groups: castration without anesthesia (NOA) and castration with anesthesia (A) with a total of three litters per treatment.

Fifteen piglets from the A group received $0.5 \mathrm{~mL}$ of intratesticular $2 \%$ lidocaine with a vasoconstrictor in each testicle, and 14 piglets from the NOA group received $0.5 \mathrm{~mL}$ of intratesticular $0.9 \%$ sodium chloride. Castration was performed 5 minutes after intratesticular injection of lidocaine (A) or saline (NOA). All surgeries were performed on the same day by two experienced surgeons. Animals from the A and NOA groups were randomly castrated by both surgeons. Piglets were restrained in the supine position and underwent antisepsis of the scrotal region. Castration was carried out by making an incision on the scrotum for exposure of the testicle. The spermatic cord was scarified with a scalpel, and the testicle was removed. The same procedure was repeated on the other side. Vocalization was subjectively assessed during surgery.

Blood samples were collected from the jugular vein of all animals for serum extraction and measurement of the cortisol concentration. Samples were collected immediately after castration and 3 and 6 days after castration. All samples were collected in the morning. The serum cortisol concentration was measured by solid-phase radioimmunoassay (Coat-A-Count Cortisol; Diagnostic Products). Animals were weighed after sampling and 3 and 6 days postoperatively.

Behavior was assessed daily for 6 days by two observers blinded to the treatment. Some of the animals were randomly assessed in the morning and some in the afternoon, ensuring that animals from both groups were similarly distributed between these periods.

Each group of pigs from each litter $(n=4-6$ animals) was simultaneously observed daily, during 90 minutes, for six days after castration. The duration of the occurrence of the following observations was measured in minutes per hour: sleeping time; time spent at the creep feeder; agonistic, stereotyped, and playing behavior; abnormal vocalization; frequency of drinking water, nursing (breast feeding), urination, defecation, scratching the surgical wound; and changes in behavior. Agonistic behavior was defined as an act of aggression or dispute between two or more piglets. Stereotyped behavior was defined as repetition of the same activities several times. Playing behavior was defined as friendly interactions between the piglets.

Statistical analysis was performed using GraphPad Software, Inc. (1998). Differences over time within the same group and between the two groups were evaluated by two- and one-way analysis of variance, respectively, followed by the Student-Newman-Keuls test. Behavior data were 
analyzed by SAS Inst., Inc., Cary, NC (1990) using a complete block design, considering each day as one block (ZAR, 1999). Mean times of six evaluations done for 90 minutes during 6 days of each behavior were compared by Tukey t test.

\section{Results}

The average time taken to restrain the pig, administering local anesthesia with automatic vaccinator and returning the animal to the same pen was 23 seconds.

In both groups, the serum cortisol concentration was greater immediately after surgery than at 3 (NOA, $p=0.01 ; \mathrm{A}, p=0.0007)$ and 6 days (NOA, $p=0.02 ; \mathrm{A}, p=0.0009$ ) postoperatively (Table 1 ).

There was no difference in weight between the groups before surgery ( $p=0.24)$. Weight was greater at $3(p=0.02)$ and 6 days $(p=0.03)$ after castration in the A group than in the NOA group (Figure 1).

Table 1. Mean \pm standard deviation of serum cortisol concentrations $\left(\mathrm{mg} \mathrm{dL}^{-1}\right)$ immediately and 3 and 6 days after castration in piglets with intratesticular lidocaine $(\mathrm{A}, n=15)$ or saline (NOA, $n=14)$

\begin{tabular}{lccc}
\hline Groups & Immediately after & Three days after & Six days after \\
NOA & surgery (A) & Surgery (B) & Surgery (C) \\
A & $9.75^{\mathrm{Aa}} \pm 8.55$ & $4.08^{\mathrm{Ba}} \pm 4.38$ & $4.80^{\mathrm{Ba}} \pm 5.51$ \\
\hline
\end{tabular}

Legend: Capital letters indicate differences within the same group over time $(A>B)$; lower case letters indicate differences between groups at each time point $(\mathrm{a}>\mathrm{b})$.

Figure 1. Weight of piglets (kg) before (D0), three (D3) and six (D6) days after castration with intratesticular lidocaine $(A, n=15)$ or saline (NOA, $n=14)$.

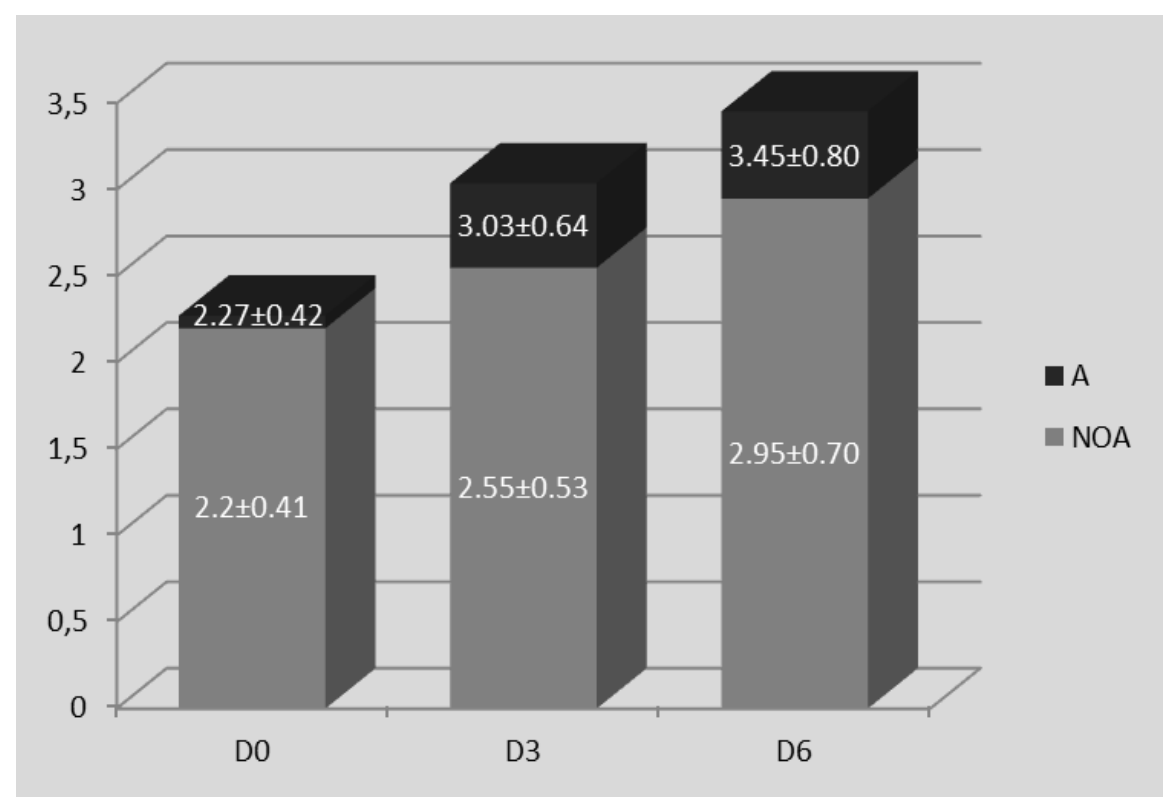

Piglets in the A group spent less time nursing (breast feeding) than did those in the NOA group (Table 2). There were no other differences between the two groups.
The most intense vocalization coincided with the surgical procedure in piglets in the NOA group. Vocalization did not coincide with the surgical procedure in anesthetized animals. 
Table 2. Mean times (minutes) for 6 days piglets spent sleeping; nursing; in agonistic stereotyped and playing behavior; at the juggler and changing activities during the 90 minute observation period at each day after castration with intratesticular lidocaine (A, $n=15)$ or saline (NOA, $n=14)$

\begin{tabular}{lcc}
\hline Activities & $\boldsymbol{A}$ & $\boldsymbol{N O A}$ \\
\hline Sleeping & 52 & 45 \\
Nursing & $14^{\mathrm{b}}$ & $21^{\mathrm{a}}$ \\
Agonistic stereotyped and playing behavior & 11 & 14 \\
At the juggler & 4 & 2 \\
Changing activities & 9 & 8 \\
\hline Total mean time & 90 & 90 \\
\hline
\end{tabular}

Legend: Superscript letters indicate differences between groups $(a>b)$.

Times are presented as minutes/observation period.

\section{Discussion}

Local anesthesia increased short term weight gain in piglets submitted to castration. This is to our knowledge the first report of the beneficial effects of local anesthesia in weight gain in piglets submitted to castration (HANSSON et al., 2011; KLUIVERSPOODT et al., 2012, 2013).

The increased weight gain in animals submitted to local anesthesia might be related to the reduction in pain produced by the antinociceptive, antiinflammatory, and antimicrobial effects of local anesthesia (RIMBÄCK et al., 1988; SAKURAGI et al., 1998; PERE et al., 1999; BATAI, 2002; CASSUTO et al., 2006). It is well known that the greater the weight gain at weaning, the greater the weight at slaughtering and the greater the profit to the producer (MAHAN; LEPINE, 1991; MAHAN et al., 1998; WOLTER; ELLIS, 2001). When a large number of animals are slaughtered, there is a potential gain in income for the producer. Apart from the economic gain, local anesthesia before castration in piglets would ensure more humanitarian management within the requirements of animal welfare.

The cortisol concentration and behavioral and weight changes have been the most common variables used to measure pain and stress in several animal species (BECKER, 1985; SAPOLSKY et al., 2000; COETZEE, 2007; SUTHERLAND et al., 2012). Castration is a known noxious and painful stimulus in piglets (HAY, 2003; MCGLONE et al., 1993; TAYLOR; WEARY, 2000; TAYLOR et al., 2001).

The higher cortisol concentration immediately after the surgery than at the other time points in both groups showed that not only did the surgery produce painful stimuli, but also that intratesticular local anesthesia and handling were stressful, as demonstrated before in piglets undergoing castration under $\mathrm{CO}_{2}$ anaesthesia (SUTHERLAND et al., 2012). Although there were no significant differences in the serum cortisol concentrations immediately after surgery between the two groups, the cortisol values in the A group were about $50 \%$ greater than those in the NOA group, different from the results reported by Kluivers-Poodt et al. (2012), which observed a smaller increase in cortisol compared with piglets castrated without anaesthesia. Jugular blood sampling is stressful and invasive and might increase serum cortisol concentration in piglets as reported elsewhere (KLUIVERS-POODT, 2007). Salivary and fecal samples might be used as alternatives for measuring cortisol concentration in pigs instead (CARLSSON et al., 2007; PARROTT; MISSON, 1989), however if one of these sources were used, neither of them would provide information in real time, i.e. it would not be possible to detect the potential immediate post-castration effect of local anesthesia in reducing cortisol concentration in piglets. Besides that several limitations may be imputed to these methods as, in 
the case of feces, $24 \mathrm{~h}$ sampling should be performed, fact that would not be possible in our circumstances as animals were maintained in groups and would not be possible to separate the feces (CARLSSON et al., 2007).

The handling for the administration of local anesthesia was apparently an additional stressful stimulus, probably produced by manipulation and/ or insertion of the needle and/or local irritation produced by the local anesthetics. The most intense vocalization coincided with the surgical procedure in piglets from the NOA group, but not in anesthetized animals; this likely indicates that vocalization was caused by the painful surgical stimulus as previously described (WHITE; MCKEITH, 1995; HANSSON et al., 2011).

Another potential stressful stimulus that might further explain the higher cortisol concentration immediately after surgery than at 3 and 6 days after surgery in both groups is that the temporary separation of the piglets from their mother was longer at this time point and that this was the first time that they had been separated from their mothers. Pigs, like other species, are very sensitive to separation from their mothers (PLOTSKY; MEANEY, 1993; BIAGINI et al., 1998; WIGGE; NEUMANN, 1999). The reduction in the serum cortisol concentration at 3 and 6 days after surgery in both groups is probably related to the fact that at these time points, the duration of the handling period was shorter than that immediately after surgery and the piglets were restrained only for blood sampling.

Schulz et al. (2007) also reported that the cortisol concentrations were higher in castrated animals with or without anesthesia than in those in the control group. However, the cortisol was lower when meloxicam was given before surgery, showing that the nonsteroidal anti-inflammatories may reduce the stress response to castration.
Pain and stress may result in behavioral changes as well as decreased food intake (DUBNER, 1987; HASKINS, 1987). Although weight gain was significantly greater in animals castrated under anesthesia in the present study, these piglets spent less time nursing. Suckling behavior is a common expression in animals under stressful conditions because the act of suckling probably releases endorphins and alleviates stress and pain (BLASS et al., 1987; CARBAJAL et al., 2003; et al., 2006). This appears to be a displacement behavior to minimize the perception of pain (WIEPKEMA, 1987), as described in human newborns (SHAH et al., 2006). It is apparently unrelated to food intake because increased suckling did not increase weight gain in the piglets from the NOA group. Although the differences were not significant, the piglets submitted to anesthesia spent a longer time sleeping, which might further explain the greater weight gain. There was no change in the "teat preference" of nursing among the piglets throughout the observation period, showing that castration did not modify the hierarchy.

The possible limitations of this study are that the animals in the A group were $70 \mathrm{~g}$ heavier than those in the NOA group at the beginning of the study, and this might have contributed to the greater weight gain in animals submitted to anesthesia. However, there was no statistical difference at baseline, and it is unlikely that this difference in weight was relevant in such a short evaluation period (6 days). Another possible limitation would be related to the differences in litters affecting the results, however care was taken to randomize and distribute litters in the two groups.

Intratesticular local anesthesia before castration in piglets is technically practical, follows good welfare practice, and improves short-term weight gain in piglets submitted to castration. However, further studies with additional data are necessary to confirm whether this is economically viable. 


\section{References}

BATAI, I. Bacterial growth in ropivacaine hydrochloride. Anesthesia and Analgesia, San Francisco, California, v. 94, n. 3, p. 729-731, 2002.

BEATTIE, V. E.; O'CONNELL, N. E.; MOSS, B. W. Influence of environmental enrichment on the behaviour, performance and meat quality of domestic pigs. Livestock Production Science, Amsterdam, v. 65, n. 1-2, p. 71-79, 2000.

BECKER, B. A. Peripheral concentrations of cortisol as an indicator of stress in the pig. American Journal of Veterinary Research, Schaumburg, v. 46, n. 5, p. 10341038, 1985.

BIAGINI, G.; PICH, E. M.; CARANI, C.; MARRAMA, P.; AGNATI, L. F. Postnatal maternal separation during the stress hyporesponsive periods enhances the adrenocortical response to novelty in adults rats by affecting feedback regulation in the CA1 hippocampal field. Internationanl Journal of Developmental Neuroscience, Oxford, v. 16, n. 3-4, p. 187-187, 1998.

BLASS, E.; FITZGERALD, E.; KEHOE, P. Interactions between sucrose, pain and isolation distress. Pharmacology, Biochemistry and Behavior, Philadelphia, v. 26, n. 3, p. 483-489, 1987.

CARBAJAL, R.; VEERAPEN, S.; COUDERC, S.; JUGIE, M.; VILLE, Y. Analgesic effect of breast feeding in term neonates: randomized controlled trial. British Medical Journal, London, v. 326, n. 4, p. 13-17, 2003.

CARLSON, L. E.; CAMPBELL, T. S.; GARLAND, S. N.; GROSSMAN, P. Associations among salivary cortisol, melatonin, catecholamines, sleep quality and stress in women with breast cancer and healthy controls. Journal of Behavioral Medicine, New York, v. 30 n. 1, p. 45-58, 2007.

CASSUTO, J.; SINCLAIR, R.; BONDEROVIC, M. Anti-inflammatory properties of local anesthetics and their present and potential clinical implications. Acta Anaesthesiologica Scandinavica, Hoboken, v. 50, n. 3, p. 265-282, 2006.

COETZEE, J. F. Attenuation of acute plasma cortisol response in calves following intravenous sodium salicylate administration prior to castration. Journal of Veterinary Pharmacology and Therapeutics, Oxford, v. 30, n. 4, p. 305-313, 2007.

DRANSFIELD, E. Consumer choice and suggested price for pork as influenced by its appearance, taste and information concerning country of origin and organic pig production. Meat Science, Barking, v. 69, n. 5, p. 61-70, 2005.
DUBNER, R. Research on pain mechanisms in animals. Journal of the American Veterinary Medical Association, New York, v. 191, n. 10, p. 1273-1276, 1987.

FOOD AND AGRICULTURE ORGANIZATION OF THE UNITED NATIONS - FAOSTAT/FAO. Sources of meat. Rome: Stylus Publishing, 2013. Available at: $\quad<$ http://www.fao.org/ag/againfo/themes/en/meat/ backgr_sources.html $>$. Acessed at: 11 mar. 2016.

GRAPHPAD SOFTWARE. InStat guide to choosing and interpreting statistical tests. San Diego: GraphPad Software Inc., 1998. Available at: <www.graphpad. com>. Acessed at: 11 mar. 2016.

HAGA, H. A.; RANHEIM, B. Castration of piglets: the analgesic effects of intratesticular and intrafunicular lidocaine injection. Veterinary Anaesthesia and Analgesia, Oxford, v. 32, n. 1, p. 1-9, 2005.

HANSSON, M.; LUNDEHEIM, N.; NYMAN, G.; JOHANSSON, G. Effect of local anaesthesia and/or analgesia on pain responses induced by piglet castration. Acta Veterinaria Scandinavica, Vanloese, v. 34, n. 1, p. 1-9, 2011.

HASKINS, S. C. Use of analgesics postoperatively and in a small intensive care setting. Journal of the American Veterinary Medical Association, New York, v. 191, n. 10, p. 1266-1268, 1987.

HAY, M. Assessment of pain induced by castration in piglets: behavioural and physiological responses over the subsequent 5 days. Applied Animal Behavior Science, Amsterdam, v. 82, n. 3, p. 201-218, 2003.

JAGGIN, N. et al. Castration of newborn piglets under inhalation anesthesia with halothane. Der Praktische Tierarzt, Hannover, v. 82, n. 12, p. 1054-1061, 2001.

KLUIVERS-POODT, M.; HOPSTER, H.; SPOOLDER, H. A. M. Castration under anaesthesia and/or analgesia in commercial pig production. Report 73. ASG. Lelystad, 2007.

KLUIVERS-POODT, M.; HOUX, B. B.; ROBBEN, S. R. M.; KOOP, G.; LAMBOOIJ, E.; HELLEBREKERS, L. J. Effects of a local anaesthetic and NSAID in castration of piglets, on the acute pain responses, growth and mortality. Animal, Cambridge, v. 6, n. 9, p. 14691475, 2012.

KLUIVERS-POODT, M.; ZONDERLAND， J. J.; VERBRAAK, J.; LAMBOOIJ, E.; HELLEBREKERS, L. J. Pain behaviour after castration of piglets; effect of pain relief with lidocaine and/or meloxicam. Animal, Cambridge, v. 7, n. 4, p. 1158-1162, 2013. 
MAHAN, D. C.; CROMWELL, G. L.; EWAN, R. C.; HAMILTON, C. R.; YEN, J. T. Evaluation of the feeding duration of a phase 1 nursery diet to three-week-old pigs of two weaning weights. NCR-42 Committee on Swine Nutrition. Journal of Animal Science, Champaign, v. 76, n. 2, p. 578-583, 1998.

MAHAN, D. C.; LEPINE, A. J. Effect of pig weaning weight and associated nursery feeding programs on subsequent performance to 105 kilograms body weight. Journal of Animal Science, Champaign, v. 69, n. 4, p. 1370-1378, 1991.

MCGLONE, J. J.; NICHOLSON, R. I.; HELLMAN, J. M.; HERZOG, D. N. The development of pain in young pigs associated with castration and attempts to prevent castration-induced behavioral changes. Journal of Animal Science, Champaign, v. 71, n. 6, p. 1441-1446, 1993.

NGAPO, T. M.; MARTIN, J. F.; DRANSFIELD, E. International preferences for pork appearance: I. Consumer choices. Food Quality and Preference, Barking, v. 18, n. 1, p. 26-36, 2007a.

NGAPO, T. M.; MARTIN, J.-F.; DRANSFIELD, E. International preferences for pork appearance: II. Factors influencing consumer choice. Food Quality and Preference, Barking, v. 18, n. 1, p. 139-151, 2007b.

PARROTT, R. F.; MISSON, B. H.. Changes in pig salivary cortisol in response to transport simulation, food and water deprivation, and mixing. British Veterinary Journal, Suffolk, v. 145, n. 6, p. 501-505, 1989.

PERE, P.; LINDGREN, L.; VAARA, M. Poor antibacterial effect of ropivacaine: comparison with bupivacaine. Anesthesiology, Philadelphia, v. 91, n. 3, p. 884-886, 1999.

PLOTSKY, P. M.; MEANEY, M. J. Early, postnatal experience alters hypothalamic corticotrophin releasing factor (CRF) mRNA, median eminence, CRF contents and stress induced release in adults rats. Brain Molecular Brain Research, Amsterdam, v. 18, n. 3, p. 195-200, 1993.

RIMBÄCK， G.; CASSUTO， J.; WALLIN， G.; WESTLANDER, G. Inhibition of peritonitis by amide local anesthetics. Anesthesiology, Philadelphia, v. 69, n. 6, p. 881-886, 1988.

ROLLIN, B. E. Farm animal welfare: social, bioethical, and research issues. Ames: State University Press, 1995. $168 \mathrm{p}$.
ROPPA, L. Carne suína: mitos e verdades. Belo Horizonte: Associação dos Suinocultores do Estado de Minas Gerais, 2003. Disponível em: $<$ http://www.asemg. com.br/asemg/publicacoes.asp? codigo $=250>$. Acesso em: 10 jul. 2012.

SAKURAGI, T.; ISHINO, H.; DAN, K. Bactericidal activity of preservative-free bupivacaine on microorganisms in the human skin flora. Acta Anaesthesiologica Scandinavica, Hoboken, v. 42, n. 9, p. 1096-1099, 1998.

SAPOLSKY, R. M.; ROMERO, L. M.; MUNCK, A. U. How do glucocorticoids influence stress responses? Integrating permissive, suppressive, stimulatory, and preparative actions. Endocrine Reviews, Chevy Chase, v. 21, n. 1, p. 55-89, 2000.

STATISTICAL ANALYSIS SYSTEM INSTITUTE - SAS. SAS User's Guide: Statistics Version 4, SAS Institute Inc., Cary, North Carolina, 1990.

SCHULZ, C.; RITZMANN, M.; PALZER, A.; HEINRITZI, K.; ZOELS, S. Effect of isoflurane inhalation anesthesia on postoperative pain due to castration of piglets. Berliner und Munchener Tierarztliche Wochenschrift, Hannover, v. 120, n. 5-6, p. 177-182, 2007.

SHAH, P. S.; ALIWALAS, L. I.; SHAH, V. Breastfeeding or breast milk for procedural pain in neonates. Cochrane Database of Systematic Reviews, West Sussex, v. 3, n. 3, p. CD004950, 2006.

SUTHERLAND, M. A.; DAVIS, B. L.; BROOKS, T. A.; COETZEE, J. F. The physiological and behavioral response of piglets castrated with and without anesthesia and analgesia. Journal of Animal Science, Champaign, v. 90, n. 7, p. 2211-2221, 2012.

TAYLOR, A. A.; WEARY, D. M. Vocal responses of piglets to castration: identifying procedural sources of pain. Applied Animal Behavior Science, Amsterdam, v. 70, n. 1, p. 17-26, 2000.

TAYLOR, A. A.; WEARY, D. M.; LESSARD, M.; BRAITHWAITE, L. Behavioural responses of piglets to castration: the effect of piglet age. Applied Animal Behavior Science, Amsterdam, v. 73, n. 1, p. 35-43, 2001.

THUN, R.; GAJEWSKI, Z.; JANETT, F. Castration in male pigs: techniques and animal welfare. Journal of Physiology and Pharmacology, Krakow, v. 57, n. 8, p. 189-194, 2006. 
UNITED STATES DEPARTMENT OF AGRICULTURE

- USDA. Foreign agricultural service. Livestock and poultry: world markets and trade. Independence Avenue: Foreign Agricultural Service, 2015. Available at: $<$ http:// apps.fas.usda.gov/psdonline/circulars/livestock_poultry. pdf>. Acessed at: 11 mar. 2016

WARRIS, P. D. Meat science: and introductory text. (Chapters 1 and 10). Wallingford: CABI Publishing, 2000. 310 p.

WHITE, B. R.; MCKEITH, F. K. Growth and body composition of Meishan and Yorkshire barrows and gilts. Journal of Animal Science, Champaign, v. 73, n. 3, p. 738-749, 1995.

WIEPKEMA, P. R. Behavioural aspects of stress. In: WIEPKEMA, P. R.; VAN ADRICHEM, P. W. (Ed.). Biology of stress in farm animals: an integrative approach. Dordrecht: Martinus Nijhoff, 1987. p. 113-131.
WIGGE, A.; NEUMANN, I. D. Periodic maternal deprivation induces gender dependent alterations in behavioral and neuroendocrine responses to emotional stress in adult rats. Physiology \& Behavior, Philadelphia, v. 66, n. 2, p. 293-302, 1999.

WOLTER, B. F.; ELLIS, M. The effects of weaning weight and rate of growth immediately after weaning on subsequent pig growth performance and carcass characteristics. Canadian Journal of Animal Science, Champaign, v. 81, n. 3, p. 363-369, 2001.

ZAR, J. H. Biostatistical analysis. $4^{\text {th }}$ ed. New Jersey: Prentice-Hall, 1999. 663 p.

ZÖLS, S.; RITZMANN, M.; HEINRITZI, K. Effect of analgesics on the castration of male piglets. Berliner und Munchener Tierarztliche Wochenschrift, Hannover v. 119, n. 5-6, p. 193-196, 2006. 
